\title{
THE EFFECT OF DAILY PHYSICAL ACTIVITY ON THE ACTIVITY OF INFLAMMATORY BOWEL DISEASES IN THERAPY-FREE PATIENTS
}

\author{
Dubravka Holik ${ }^{1}$, Aleksandar Včev ${ }^{1,2}$, Andrea Milostić-Srb² ${ }^{2}$ Željka Salinger ${ }^{3}$, \\ Zrinka Ivanišević ${ }^{2}$ Ivan Včev ${ }^{4}$ and Maja Miškulin ${ }^{1}$ \\ ${ }^{1}$ Faculty of Medicine, Josip Juraj Strossmayer University of Osijek, Osijek, Croatia; \\ ${ }^{2}$ Faculty of Dental Medicine and Health, Josip Juraj Strossmayer University of Osijek, Osijek, Croatia; \\ ${ }^{3}$ Department of Mathematics, Josip Juraj Strossmayer University of Osijek, Osijek, Croatia; \\ ${ }^{4}$ University of Zadar, Zadar, Croatia
}

\begin{abstract}
SUMMARY - It has been suggested that various environmental factors play a very important role in the etiology of inflammatory bowel diseases (IBDs) and that they have a significant effect on the course of these diseases. The aim of this study was to investigate the effect of daily physical activity on the activity of IBDs in therapy-free patients. This cross-sectional population based study was conducted in eastern Croatia from January to June 2016. The study included 312 patients, mean age $49.9 \pm 15.0$ years, $53.2 \%$ of males and $46.8 \%$ of females; there were $63.4 \%$ of ulcerative colitis (UC) and $36.6 \%$ of Crohn's disease (CD) patients. Sociodemographic characteristics of patients, data on their daily physical activity and type of therapy taken were collected through a specifically designed and validated questionnaire, while the activity of $\mathrm{UC}$ and $\mathrm{CD}$ was evaluated using the Mayo index and Harvey-Bradshaw index. The study showed that $24.0 \%$ of patients were not taking therapy. Daily physical activity was connected to IBD in study patients when taking both diseases collectively (Fisher exact test; $\mathrm{p}<0.001$ ), as well as to the inactivity of $\mathrm{CD}$ (Fisher exact test; $\mathrm{p}=0.001$ ) and UC (Fisher exact test; $p=0.006$ ), when observing each disease separately. Daily physical activity was connected to the inactivity of IBDs in patients not taking therapy. It is necessary to educate all IBD patients about the importance of physical activity in order to control their disease.
\end{abstract}

Key words: Inflammatory bowel diseases; Colitis, ulcerative; Crobn's disease; Exercise; Croatia

\section{Introduction}

Inflammatory bowel diseases (IBDs) are chronic inflammatory diseases of the gastrointestinal tract that include the two most common separate entities, ulcerative colitis (UC) and Crohn's disease (CD). These diseases are characterized by chronic inflammatory destruction of the intestinal wall and the periods of exacerbation and remission of clinical symptoms ${ }^{1-4}$.

Correspondence to: Prof. Maja Miškulin, MD, PhD, Faculty of Medicine, Josip Juraj Strossmayer University of Osijek, Josipa Huttlera 4, HR-31000 Osijek, Croatia

E-mail: maja.miskulin@mefos.hr

Received May 29, 2018, accepted July 3, 2018
The increase in the incidence and prevalence of IBDs in the last several decades has been recorded in all regions of the world, even though there are variations among countries ${ }^{5,6}$. The areas with a traditionally high incidence of IBDs are North America and northern and western Europe, and a recent research conducted in eastern Europe and Asian countries showed a constant increase in the number of newly affected patients ${ }^{5}$. The increase in the IBD incidence recorded in those regions of the world can be explained by changes in the environmental factors ${ }^{7}$ and lifestyle factors affecting clinical expression of these diseases ${ }^{8}$. Croatia is also a good example of this concept ${ }^{9-11}$. Experts agree that IBD etiology is multifactorial, while a 
significant factor in the etiology is complex interaction of genetic susceptibility, immune system, intestinal microbiome ${ }^{12}$, and various environmental factors ${ }^{13}$. It is considered that environmental factors and life habits carry $70 \%$ of the risk for the occurrence of IBD, and that they have a significant effect on the course of these diseases ${ }^{14}$, even though data are still limited ${ }^{8}$.The first-line treatment is medication, but when the disease does not respond or when complications arise and there is the need to relieve symptoms, surgery is required $^{15}$. Treating an IBD with conventional medications is often not fully effective, there are numerous unwanted side effects, and it is a significant economic burden. As a consequence of all this, there is the need for new ways and approaches to treatment, where applying physical exercise as a supplemental method for controlling these diseases appears as a highly interesting option ${ }^{16,17}$. Research has shown that physical activity improves health and quality of life of chronic patients through anti-inflammatory activity. IBD patients can handle low and medium intensity physical exercise, which has a beneficial effect on the course of their disease ${ }^{17,18}$. Physical exercise is also recommended for IBD patients having developed disease complications because it contributes to improving mineral density of bones, immune response, better stress management, maintaining body mass, and entire body condition ${ }^{19}$. There is not much clinical research in the literature that examined the effect of physical activity on IBD activity ${ }^{20}$. Even though it has been confirmed that exercise is useful and safe for IBD patients, there are still no defined guidelines that could be recommended to patients ${ }^{17}$. It is not known to what extent and intensity regular exercise has a therapeutic effect on IBD activity $^{20}$. It is necessary to continuously evaluate the effect of regular exercise, since it changes the occurrence patterns and IBD activity in the population. The aim of this study was to investigate the effect of daily physical activity on the activity of IBDs in therapyfree patients, collectively for both diseases and separately for $\mathrm{CD}$ and $\mathrm{UC}$.

\section{Patients and Methods}

\section{Study design}

This cross-sectional study was conducted from January to June of 2016 in eastern Croatia in VukovarSrijem County, Požega-Slavonia County, and Virovit-
ica-Podravina County. All IBD patients from these counties, treated for IBD at Vukovar General County Hospital, Vinkovci General County Hospital, Požega General County Hospital and Virovitica General County Hospital, were asked to participate in the study. The aim and purpose of the study were previously explained to them in detail. The response rate was $93.7 \%$ (312/333). The study was approved by the Ethics Committee of the Josip Juraj Strossmayer University of Osijek, Faculty of Medicine in Osijek (approval no. 2158-61-07-17-19).

\section{Study participants}

The study included 312 adult patients suffering from IBDs. A written informed consent was obtained from all participants. The mean age of study patients was $49.9 \pm 15.0$ years. There were $53.2 \%$ of male and $46.8 \%$ of female patients; $36.6 \%$ of $\mathrm{CD}$ patients and $63.4 \%$ of UC patients.

\section{Methods}

A specially designed anonymous questionnaire was used as a research tool in order to determine the type of IBD in study patients, their sociodemographic characteristics (sex, age, county of residence, job status, marital status, level of education, socioeconomic status), and anthropometric characteristics (height, mass, body mass index (BMI)). A special category of questions was related to personal medical history (age when the diagnosis was set, duration of disease), type of therapy and disease activity (Harvey-Bradshaw index for CD activity assessment and Mayo index for UC activity assessment, as well as disease phenotype according to the Montreal classification), and family medical history. The study questionnaire provided information related to life habits of the patients, which included alcohol consumption and smoking, dietary habits, daily physical activity and its intensity, as well as using complementary treatment methods. Regarding dietary habits, the questionnaire determined the number of meals the patients were currently taking daily, and whether the number of meals had changed after IBD diagnosis, the most represented group of groceries in the meals before and after IBD diagnosis, and taking a special diet as supplementary treatment in controlling IBD symptoms. Daily physical activity by the study participants was categorized as low 
Table 1. Phenotypic characteristics of inflammatory bowel disease patients

\begin{tabular}{|c|c|c|c|c|c|c|}
\hline \multicolumn{2}{|c|}{ Phenotypic characteristic } & \begin{tabular}{|l} 
Ulcerative \\
colitis \\
$(\mathrm{N}=198)$ \\
\end{tabular} & n (\%) & $\begin{array}{l}\text { Crohn's } \\
\text { disease } \\
(\mathrm{N}=114) \\
\end{array}$ & n (\%) & $\mathrm{p}$ \\
\hline $\begin{array}{l}\text { Disease } \\
\text { duration }\end{array}$ & $\begin{array}{l}\text { Age at diagnosis (yrs) } \\
\text { medians (Q1, Q3) } \\
\text { Disease duration (yrs) } \\
\text { medians (Q1, Q3) }\end{array}$ & $\begin{array}{l}41.0(30,53) \\
7.0(5,12)\end{array}$ & & $\begin{array}{l}35.5(26,48) \\
7.0(4,12)\end{array}$ & & $\begin{array}{l}0.009^{*} \\
0.597^{*}\end{array}$ \\
\hline $\begin{array}{l}\text { Montreal } \\
\text { classification }\end{array}$ & $\begin{array}{l}\text { Age at diagnosis (yrs) (A) } \\
\text { Extent(E)/ } \\
\text { location (L) }\end{array}$ & $\begin{array}{l}\text { E1 (proctitis) } \\
\text { E2 } \\
\text { (left side) } \\
\text { E3 } \\
\text { (extensive } \\
\text { colitis) } \\
\\
- \\
- \\
- \\
-\end{array}$ & $\begin{array}{l}- \\
- \\
- \\
51(26.0 \%) \\
117(59.0 \%) \\
30(15.0 \%)\end{array}$ & $\begin{array}{l}\text { A1 (age } \leq 16) \\
\text { A2 (17-40) } \\
\text { A3 (>40) } \\
\text { L (ileal) } \\
\text { L2 (colonic) } \\
\text { L3 (ileocolonic) } \\
\text { L4 (upper GI) } \\
\text { B1 } \\
\text { (inflammatory) } \\
\text { B2 } \\
\text { (stricturing) } \\
\text { B3 } \\
\text { (penetrating) } \\
\text { P (perianal) }\end{array}$ & $\begin{array}{l}6(5.0 \%) \\
59(52.0 \%) \\
49(43.0 \%) \\
21(18.0 \%) \\
61(53.0 \%) \\
32(28.0 \%) \\
0 \\
66(58.0 \%) \\
39(34.0 \%) \\
9(8.0 \%) \\
0 \\
\end{array}$ & $\begin{array}{l}- \\
- \\
- \\
- \\
- \\
- \\
-\end{array}$ \\
\hline Disease activity & $\begin{array}{l}\text { Mayo index } \\
\text { Active disease } \\
\text { Inactive disease } \\
\text { HBI } \\
\text { Active disease } \\
\text { Inactive disease } \\
\end{array}$ & $\begin{array}{l}79(40.0 \%) \\
119(60.0 \%) \\
- \\
-\end{array}$ & & $\begin{array}{l}- \\
- \\
39(34.0 \%) \\
75(66.0 \%)\end{array}$ & & $0.335 \dagger$ \\
\hline
\end{tabular}

HBI = Harvey-Bradshaw index; median $(\mathrm{Q} 1, \mathrm{Q} 3)$ = interquartile range; *Mann Whitney $U$ test; $†$ Fisher exact test

(30-minute walk), moderate (bicycle ride, gardening), and intensive (hard manual work, sports). The final group of questions in the study questionnaire provided data on the environmental risk factors, which included water supply method and quality of drinking water used by the study participants daily, and exposure to wartime events in the past. When implementing the questionnaire, study participants answered questions asked by the researchers, and the entire process of data collection from each patient took 15 minutes on average. The questionnaire used in this study was previously validated in a smaller group of participants in
2015. In the present study, questions about the sociodemographic characteristics of the study participants, questions about the phenotype characteristics and the type of therapy the study participants were currently taking, questions about family medical history, IBD activity and questions about daily physical activity were analyzed.

\section{Statistics}

Categorical data were expressed as absolute and relative frequencies. Numerical data were described using arithmetic mean and standard deviation for nor- 
Table 2. Type of therapy according to disease phenotype

\begin{tabular}{|l|l|l|l|l|}
\hline Therapy & $\begin{array}{l}\text { Ulcerative colitis } \\
(\mathrm{N}=198)\end{array}$ & $\begin{array}{l}\text { Crohn's disease } \\
(\mathrm{N}=114)\end{array}$ & $\begin{array}{l}\text { Total } \\
(\mathrm{N}=312)\end{array}$ & $\mathrm{p}$ \\
\hline Therapy-free patients & $56(28.3 \%)$ & $19(16.7 \%)$ & $75(24.0 \%)$ & \\
\hline $\begin{array}{l}\text { 5-ASA } \\
\text { (sulfasalazine, Pentasa, Salofalk, Asacol) }\end{array}$ & $109(55.0 \%)$ & $40(35.0 \%)$ & $149(47.8 \%)$ & $<0.001^{*}$ \\
\cline { 1 - 1 } $\begin{array}{l}\text { Other types of therapy } \\
\text { (corticosteroids, immunosuppression, anti-TNF, } \\
\text { a combination of medicines) }\end{array}$ & $33(23.0 \%)$ & $55(59.0 \%)$ & $88(28.2 \%)$ & \\
\hline
\end{tabular}

*Fisher exact test; ASA = aminosalicylic acid; $\mathrm{TNF}=$ tumor necrosis factor

Table 3. Inflammatory bowel disease activity according to type of therapy

\begin{tabular}{|l|l|l|l|l|}
\hline Therapy & $\begin{array}{l}\text { Inactive IBD } \\
(\mathrm{N}=194)\end{array}$ & $\begin{array}{l}\text { Active IBD } \\
(\mathrm{N}=118)\end{array}$ & $\begin{array}{l}\text { Total } \\
(\mathrm{N}=312)\end{array}$ & $\mathrm{p}$ \\
\hline Therapy-free patients & $57(29.4 \%)$ & $18(15.2 \%)$ & $75(24.0 \%)$ & \\
\hline $\begin{array}{l}\text { 5-ASA } \\
\text { (sulfasalazine, Pentasa, Salofalk, Asacol) }\end{array}$ & $85(43.8 \%)$ & $64(54.2 \%)$ & $149(47.8 \%)$ & \\
\cline { 1 - 1 } $\begin{array}{l}\text { Other types of therapy } \\
\text { (corticosteroids, immunosuppression, anti-TNF, } \\
\text { a combination of medicines) }\end{array}$ & $52(26.8 \%)$ & $36(30.5 \%)$ & $88(28.2 \%)$ & $0.016^{*}$ \\
\hline
\end{tabular}

*Fisher exact test; IBD = inflammatory bowel disease; ASA = aminosalicylic acid; TNF = tumor necrosis factor

mal data distribution, and median and interquartile range for those with non-normal distribution. Differences in categorical variables were tested using the $\chi^{2}-$ test and Fisher exact test if necessary. KolmogorovSmirnov test was used to test normal data distribution. Differences in normally distributed numerical variables between two independent groups were tested using Student's t-test and Mann-Whitney U test in case of deviation from normal distribution. All $\mathrm{p}$ values were two-tailed. The significance of differences determined by statistical testing was set at $\mathrm{p}<0.05$. The Statistica for Windows 2010 (version 10.0, StatSoft Inc., Tulsa, OK) statistical software package was used on data analysis ${ }^{21}$.

\section{Results}

The study included 312 participants, $63.4 \%$ with UC and $36.6 \%$ with CD. There were $53.2 \%$ of male and $46.8 \%$ of female patients. The patients with UC were significantly older, median age 54 years (interquartile range: 39-61), age range from 18 to 89 (MannWhitney U test, $\mathrm{p}=0.010$ ). When observing study participants according to the place of residence, $55.4 \%$ of
IBD patients lived in urban areas and $52.6 \%$ of them were of average economic status. According to anthropological data, CD patients were significantly taller (Mann Whitney U test, $\mathrm{p}=0.004$ ) with a significantly lower BMI (Mann Whitney U test, $\mathrm{p}=0.020$ ), as compared to UC patients. There was no statistically significant difference in BMI categories according to type of IBD ( $\chi^{2}$-test, $\left.\mathrm{p}=0.090\right)$.

The patients with UC were significantly older at the time of diagnosis (Mann Whitney U test, $\mathrm{p}=0.009$ ), when compared to $\mathrm{CD}$ patients with similar disease duration. According to the Montreal classification, $59.0 \%$ of UC patients had left-sided colitis (E2), in $53.0 \%$ of patients CD was localized in the colon (L2), and in $58.0 \%$ it was of a non-stricturing (B1) phenotype. The disease was active in 118 (38\%) study patients, 39 (34.0\%) of them with CD and 79 (40.0\%) with UC (Table 1).

Medication for IBD was currently used by 237 (76.0\%) study patients, significantly more among those with $\mathrm{CD}$ (Fisher exact test, $\mathrm{p}=0.030$ ). The most commonly used therapy were agents with aminosalicylates (sulfasalazine, Pentasa, Salofalk, Asacol), taken by 149 (47.8\%) patients. There was a significant differ- 
Table 4. Effect of daily physical activity on inflammatory bowel disease activity

\begin{tabular}{|l|l|l|l|l|}
\hline $\begin{array}{l}\text { Daily physical } \\
\text { activity }\end{array}$ & $\begin{array}{l}\text { Inactive IBD } \\
(\mathrm{N}=194)\end{array}$ & $\begin{array}{l}\text { Active IBD } \\
(\mathrm{N}=118)\end{array}$ & $\begin{array}{l}\text { Total } \\
(\mathrm{N}=312)\end{array}$ & $\mathrm{p}$ \\
\hline No & $30(15.0 \%)$ & $39(33.0 \%)$ & $69(22.0 \%)$ & $<0.001^{*}$ \\
Yes & $164(85.0 \%)$ & $79(67.0 \%)$ & $243(78.0 \%)$ & \\
\hline
\end{tabular}

* $\chi^{2}$-test; IBD = inflammatory bowel disease

Table 5. Effect of daily physical activity intensity on inflammatory bowel disease activity

\begin{tabular}{|l|l|l|l|l|}
\hline $\begin{array}{l}\text { Intensity of daily } \\
\text { physical activity }\end{array}$ & $\begin{array}{l}\text { Inactive IBD } \\
(\mathrm{N}=164)\end{array}$ & $\begin{array}{l}\text { Active IBD } \\
(\mathrm{N}=79)\end{array}$ & $\begin{array}{l}\text { Total } \\
(\mathrm{N}=243)\end{array}$ & $\mathrm{p}$ \\
\hline $\begin{array}{l}\text { Low } \\
\text { Moderate }\end{array}$ & $75(46.0 \%)$ & $34(43.0 \%)$ & $109(45.0 \%)$ & \\
Intensive & $73(45.0 \%)$ & $38(48.0 \%)$ & $\begin{array}{l}111(36.0 \%) \\
23(9.0 \%)\end{array}$ & $0.880^{*}$ \\
\hline
\end{tabular}

*Fisher exact test; IBD = inflammatory bowel disease

ence in the type of therapy taken by patients according to the disease phenotype (Fisher exact test, $\mathrm{p}<0.001$ ) (Table 2) and disease activity (Fisher exact test, $\mathrm{p}=0.016$ ) (Table 3).

Daily physical activity was practiced by 243 (77.9\%) study patients, with approximately similar number practicing low (30-minute walk) and moderate (bicycle ride, gardening) activity, and only 23 (9.0\%) practiced intensive physical activity (hard manual work, sports). A significant difference in disease activity was found between patients practicing low physical activity and those that did not practice daily physical activity. Inactive disease was present in 164 (84.5\%) study par- ticipants engaged in daily physical activity ( $\chi^{2}$-test, $\mathrm{p}<0.001$ ) (Table 4).

The intensity of daily physical activity did not affect disease activity (Fisher exact test, $\mathrm{p}=0.880$ ) (Table 5).

The study showed that $75(24.0 \%)$ study participants did not take therapy and they were included in further statistical analysis in order to determine the effect of daily physical activity on disease activity without the effects of therapy. Daily physical activity was significantly connected to the inactive stage of IBD (Fisher exact test, $\mathrm{p}<0.001$ ), regardless of the intensity of daily physical activity (Fisher exact test, $\mathrm{p}=0.157$ ) (Fig. 1).

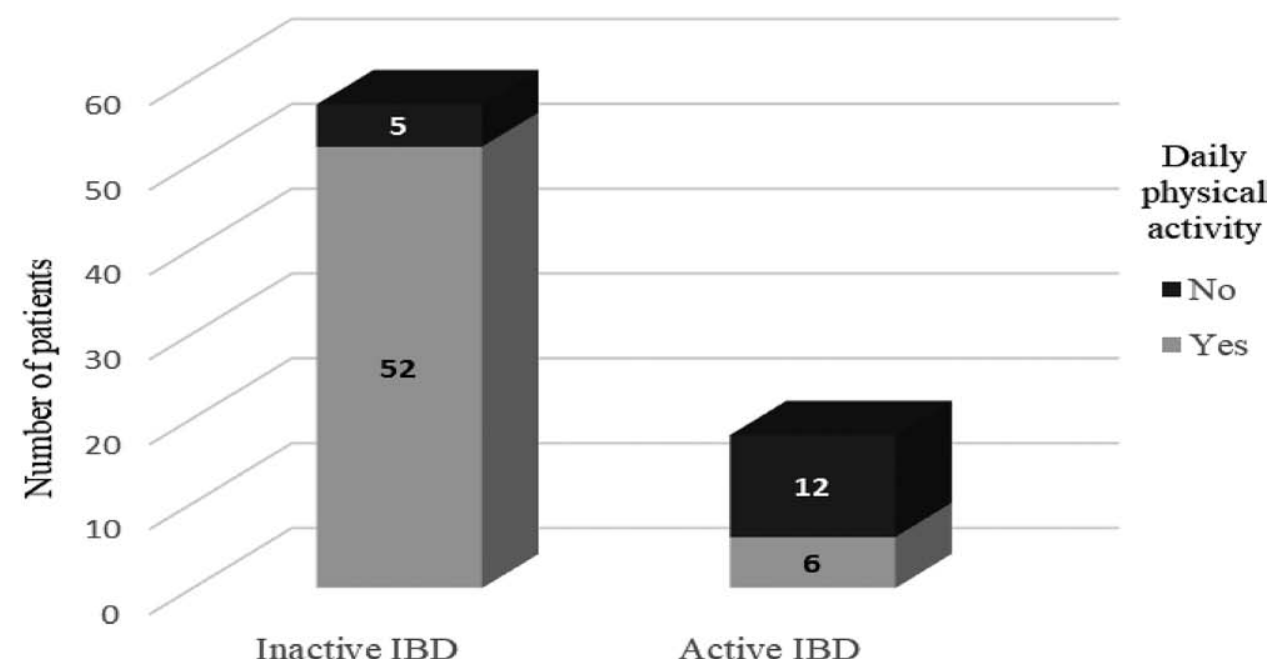

Fig. 1. Effect of daily physical activity on inflammatory bowel disease (IBD) in therapy-free patients ( $p<0.001$; Fisher exact test). 


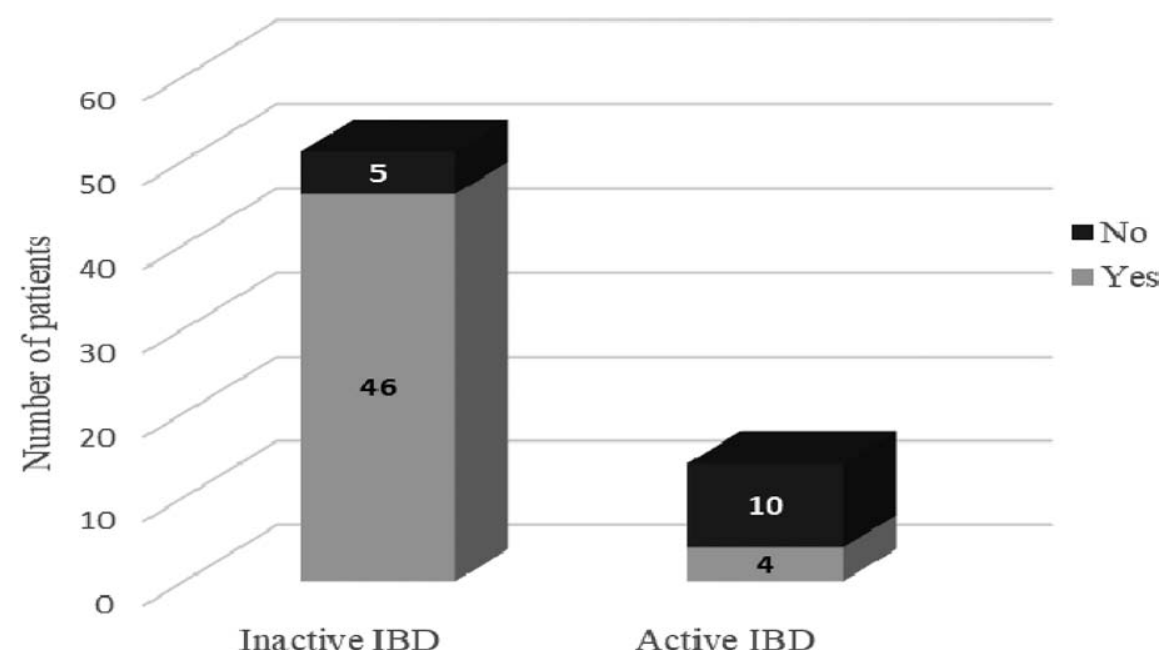

Fig. 2. Effect of daily physical activity on inflammatory bowel disease (IBD) in therapy-free patients and patients without a family history ( $p<0.001$; Fisher exact test).

These data remained significant even after the effect of family medical history for IBD was excluded (Fisher exact test, $\mathrm{p}<0.001$ ) (Fig. 2).

A significant connection was also determined between daily physical activity and the inactive stage of the disease for both $\mathrm{CD}$ (Fisher exact test, $\mathrm{p}<0.001$ ) and UC (Fisher exact test, $\mathrm{p}=0.004$ ) patients when observing each disease separately (Figs. 3 and 4).

These data remained significant even after the effect of family medical history for CD (Fisher exact test, $\mathrm{p}=0.001$ ) and UC (Fisher exact test, $\mathrm{p}=0.006$ ) was excluded.

\section{Discussion}

This study, which included 312 IBD patients, assessed positive effects of physical activity on IBD activity. The study showed that $77.9 \%$ of IBD patients were practicing daily physical activity; in $84.5 \%$ of these, the disease was inactive regardless of the intensity of daily physical activity. Similar to our study, a recent study conducted in Great Britain on 918 IBD patients showed that 665 of them were currently exercising, $32 \%$ of them daily, $57 \%$ weekly, and the rest monthly or less. Of those currently exercising, $72 \%$ said that they felt better after exercising and that exercise helped them control IBD symptoms, improved their sleep, and helped in managing their weight ${ }^{22}$. A recent study also confirmed that $82 \%$ of IBD patients regularly exercised at a varying intensity, while $40 \%$ of patients said that the disease limited their exercise, mostly because of fatigue, weakness, abdominal pain, and embarrassment ${ }^{17}$. Opposite to it, a recent study by Tew et al., conducted using an online survey in 859 adult IBD patients found that only $17 \%$ of patients belonged to the category of highly physically active individuals, $50 \%$ were engaged only in minor physical activity, and $33 \%$ were physically inactive. The most common physical activity was walking, while physical activity was limited for many patients due to fatigue, abdominal pain, immediate need to use toilet, and disease relapse ${ }^{23}$. Several studies also confirmed the low percentage of exercise among IBD patients. A study conducted in Italy on 552 IBD patients showed that only $25.6 \%$ of patients exercised regularly ${ }^{24}$, while a study conducted in Canada on $474 \mathrm{CD}$ patients and 637 UC patients found that $58 \%$ of them were physically inactive, $25 \%$ were moderately active, and $18 \%$ were practicing intense physical exercise. The most common physical activity was walking, gardening, and exercise at home ${ }^{25}$.

The question of how exercise can be used as supplemental therapy in treating these diseases is still intriguing ${ }^{17}$, and the existing studies on the connection between physical activity and IBDs are still providing conflicting results ${ }^{26}$. Due to the unpredictable course and chronicity of the diseases and the fact that these diseases are diagnosed earlier in life, the need for expensive IBD treatment and hospitalization represents a major public health problem. Any form of preventive 


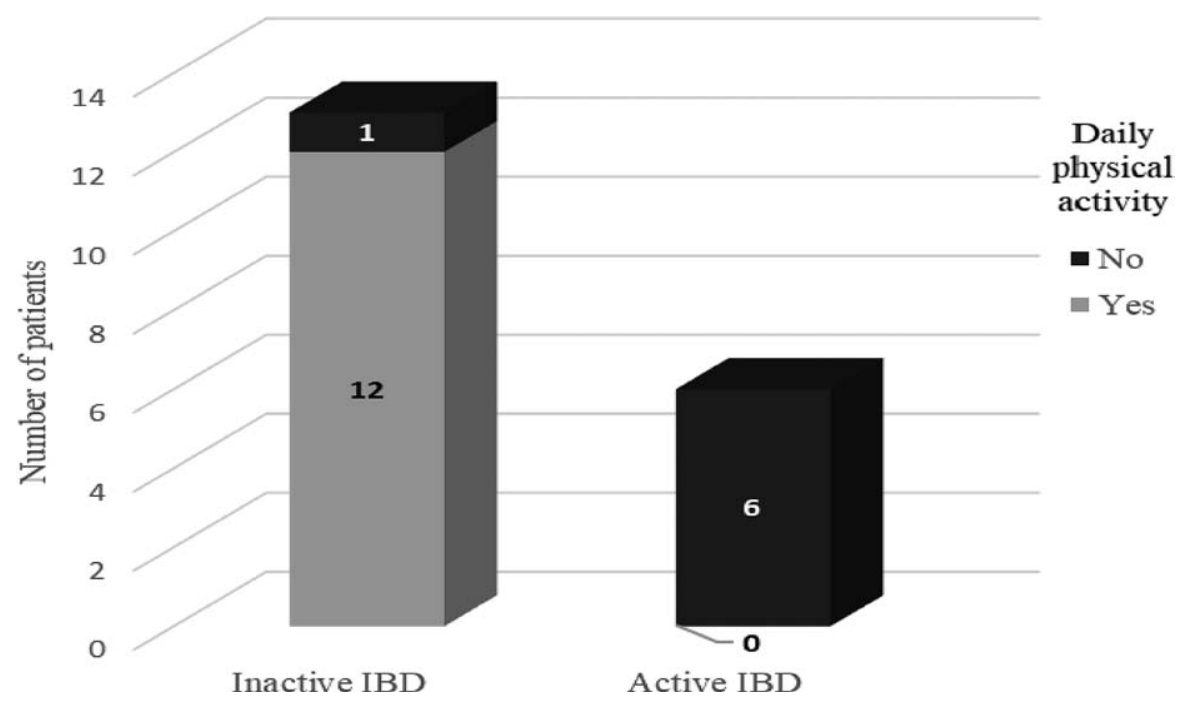

Fig. 3. Effect of daily physical activity on Crohn's disease activity in therapy-free patients ( $p<0.001$; Fisher exact test).

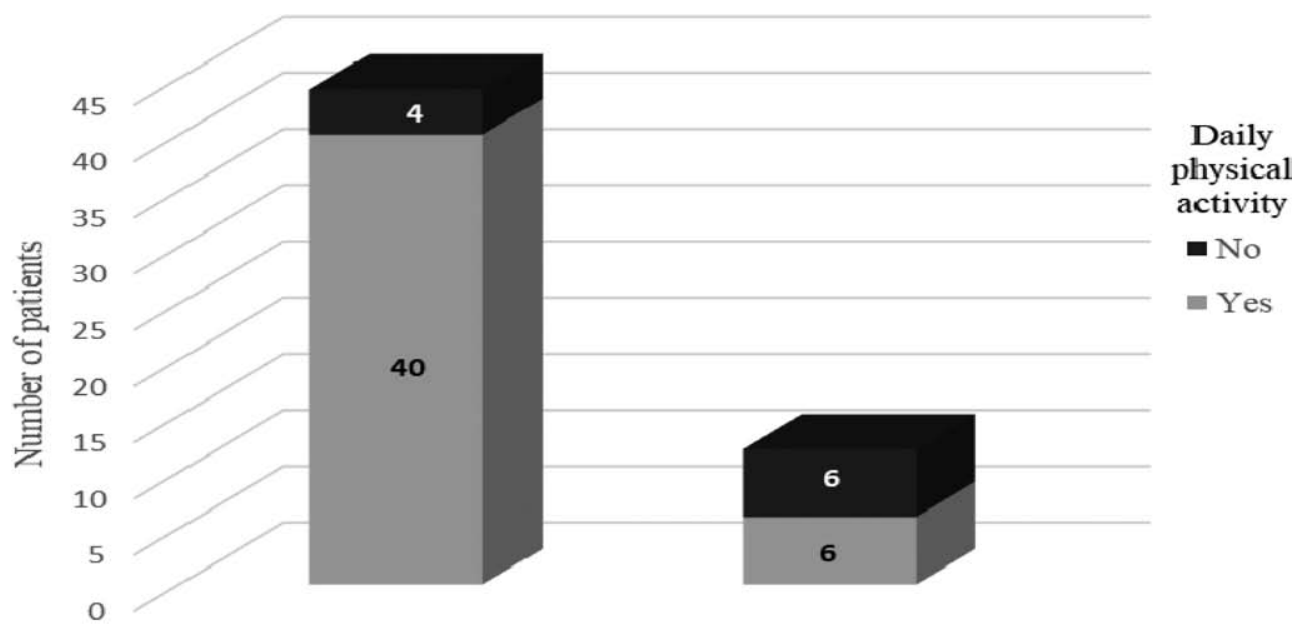

Inactive IBD

Active IBD

Fig. 4. Effect of daily physical activity on ulcerative colitis activity in therapy-free patients ( $p=0.004$; Fisher exact test).

action could reduce the incidence of these diseases and the occurrence of exacerbation ${ }^{27,28}$. Even though there is an efficient therapy for these chronic diseases, traditional treatment is not effective in some patients. $\mathrm{Pa}-$ tients are often left frustrated because of the incomplete treatment of their symptoms and they often try to find alternative or complementary forms of treatment, which could mitigate the symptoms of the disease and extend the remission period ${ }^{29}$. Previous studies have confirmed that regular exercise has a beneficial effect on health, reduces the risk of cardiovascular dis- eases, endocrine diseases, inflammatory diseases, anxiety, depression, and mortality $22,29,30$. Regular exercise improves the immune function by releasing anti-inflammatory cytokines and myokines from skeletal muscles, which inhibit the release of anti-inflammatory mediators from visceral fat tissue. Interleukin-6 released during exercise increases the release of glucagon-like peptides necessary for the repair of damaged intestinal mucosa ${ }^{29,31-35}$. Aside from the anti-inflammatory effect, exercise has a positive effect on the conditions that occur as complications of the underlying 
disease, improves the mood, contributes to the improvement of bone mineral density, improves physical fitness, contributes to the management of body mass, and improves the quality of life ${ }^{20,36,37}$. Preliminary studies have revealed that exercise can reduce stress, mitigate the symptoms of IBDs and improve the quality of life without changing the disease activity or the occurrence of disease relapse ${ }^{38,39}$. The present study indicated a significant connection between daily physical activity and the inactive stage of IBD in study participants that were not taking conventional medication for the treatment of their disease. Study results showed a significant positive effect of daily physical activity on the inactive stage of $\mathrm{CD}$ and $\mathrm{UC}$, when observing each disease separately. The positive effect of daily physical activity on the inactivity of IBDs was confirmed in study participants that were not taking conventional therapy and had no adverse influences from their family medical history.

The authors of a prospective study investigating the effect of exercise on IBD activity report that the increase in the level of exercise within 6 months reduced the risk of active disease by $32 \%$ for CD and by $24 \%$ for UC. The reduced risk remained after the level of exercise had been adjusted for age, education, use of corticosteroids, BMI, smoking, and disease duration ${ }^{19}$. Along with the significant connection of daily physical activity with the inactive stage of IBDs for IBD patients not taking conventional therapy, which was determined, the present study confirmed a significant connection which did not depend on the intensity of physical activity. This independence represents a factor in favor of the claim that physical activity is not too strenuous and that it is safe for patients. Therefore, we could say that physical activity is a special environmental factor with a protective function in the development and course of IBD. This was also confirmed by studies conducted in south-western China and Asia ${ }^{40,41}$. Recent studies confirmed good tolerability and safety of low and moderate intensity physical activity for IBD patients ${ }^{18,34,35-42}$. Exercise is pleasurable, but it is also a sort of a challenge for CD and UC patients because the symptoms of the disease such as diarrhea, abdominal pain, fatigue, and incontinence may be an obstacle to regular exercise. Once the patients feel well enough, they should be encouraged and included in physical activity corresponding to the disease activity and patient age ${ }^{1}$. The importance of self-heal- ing is often emphasized today; it consists of recognizing the symptoms, managing and planning life habits, and accepting the existing condition. A precondition for self-healing is the decision of the patient to actively participate in the care of their disease. Healthcare workers must consider the patient's potential for self-healing and adjust their advice accordingly. A previous study revealed that physical activity could be useful for mitigating IBD symptoms and that low to medium intensity training had a positive effect on the psychological condition and improved the quality of life. It is necessary to find and evaluate the duration and intensity of physical activity for each individual IBD patient, which will have a positive effect on keeping the disease in remission ${ }^{43}$. There are still no defined guidelines related to physical activity that could be recommended to all IBD patients, even though numerous studies have shown a beneficial and useful effect on the development and course of these diseases. It is difficult to define and implement universal guidelines regarding this matter for every patient, but it is necessary to emphasize the importance of exercise because fatigue and reduced physical fitness are often present in patients, even when the disease is in remission ${ }^{16,44}$.

Genetic heritage cannot be affected because it cannot be changed, but we can affect the environmental factors and life habits in our lives, and by doing so, reduce the risk of IBD occurrence. The approach to treatment for IBD patients should be holistic and integrative in order to mitigate the symptoms of the disease, extend the remission stage, and improve the quality of life. The exercise program should be adjusted for every patient according to disease severity, the patient's general condition, and their physical fitness. Patients should be encouraged to engage in physical activity because it is useful, safe, and economically justified for the treatment of these chronic diseases.

The limitation of this study was its design, so we were unable to fully follow the effect of daily physical activity on IBD activity over a longer period, and secondly, the possibility of unintentional influence on the answers of the study participants due to the survey being conducted by a person asking questions instead of the participants filling in the questionnaire by themselves. It is difficult to fully compare our study with the studies published so far because there are no studies that investigated the effect of daily physical activity on IBD activity in patients not taking conventional ther- 
apy for its treatment and those not having a positive family medical history. This study raised several questions: to what extent can daily physical activity, on its own, affect the course and activity of IBD, extend the inactive period of the disease and fully reduce the need for conventional medications? As a consequence, daily physical activity would exceed the level of supplemental therapy in the treatment of these diseases.

\section{Conclusion}

Considering that guidelines related to physical activity that could be recommended to patients have not been defined so far, further prospective cohort studies and experimental clinical studies are needed in order to answer these questions. This study conducted in eastern Croatia was carried out to emphasize the effect of environmental factors and life habits on disease activity during the study period. The results indicated a significant connection between daily physical activity and the inactive stage of $\mathrm{CD}$ and $\mathrm{UC}$ in patients not taking conventional medications. Therefore, we conclude that daily physical activity is an isolated environmental factor with a positive effect on the course of these chronic diseases.

\section{References}

1. Misra SM. Integrative therapies and pediatric inflammatory bowel disease: the current evidence. Children. 2014;1(12): 149-65, http://dx.doi.org/10.3390/children1020149

2. Fofanova TY, Petrosino JF, Kellermayer R. Microbiome-epigenome interactions and the environmental origins of inflammatory bowel diseases. J Pediatr Gastroenterol Nutr. 2016; 62(6):208-19, http://dx.doi.org/10.1097/MPG.00000000000 00950

3. Hanauer SB. Inflammatory bowel disease: epidemiology, pathogenesis, and therapeutic opportunities. Inflamm Bowel Dis. 2006;12(1): S3-9.

4. Goyette P, Labbé C, Trinh TT, Xavier RJ, Rioux JD. Molecular pathogenesis of inflammatory bowel disease: genotypes, phenotypes and personalized medicine. Ann Med. 2007;39(3): 177-99, http://dx.doi.org/10.1080/07853890701197615

5. Vegh Z, Kurti Z, Lakatos P. The epidemiology of inflammatory bowel diseases from west to east. J Dig Dis. 2017;18(2):92-8, http://dx.doi.org/10.1111/1751-2980.12449

6. Lofthus EV. Clinical epidemiology of inflammatory bowel disease: incidence, prevalence, and environmental influences. Gastroenterology. 2004;126(6):1504-17.
7. Dutta AM, Chacko A. Influence of environmental factors on the onset and course of inflammatory bowel disease. World J Gastroenterol. 2016;22:1088-100, http://dx.doi.org/10.3748/ wjg.v22.i3.1088

8. Vcev A, Pezerovic D, Jovanovic Z, Nakic D, Vcev I, Majnaric $\mathrm{Lj}$. A retrospective, case-control study on traditional environmental risk factors in inflammatory bowel disease in VukovarSrijem County, north-eastern Croatia, 2010. Wien Klin Wochenschr. 2015;127(9-10):345-54, http://dx.doi.org/10.1007/ s00508-015-0741-7

9. Pezerović D, Klarin I, Žulj M, Majnarić Lj, Khaznadar E, Včev A. Incidence and prevalence of inflammatory bowel disease in Vukovarsko-srijemska County, Croatia, 1991-2000 and 2001-2010: a population-based study. Coll Antropol. 2014;38 (1):115-23.

10. Klarin I, Majnarić LJ, Jovanović Ž, Nakić D, Včev I, Včev A. Epidemiology and clinical presentation of inflammatory bowel disease in Zadar County, Croatia. Coll Antropol. 2013;37 (4):1161-70

11. Mijandrusic Sincic B, Vucelic B, Persic M, Brncic N, Jurisic Erzen D, Radakovic B, et al. Incidence of inflammatory bowel disease in Primorsko-goranska County, Croatia, 2000-2004: a prospective population-based study. Scand J Gastroenterol. 2006;4(4):437-44, http://dx.doi.org/10.1080/0036552050032 0094

12. Aujnarain A, Mack DR, Benchimol EI. The role of the environment in the development of pediatric inflammatory bowel disease. Curr Gastroenterol Rep. 2013;15(6):326, http://dx.doi. org/10.1007/s11894-013-0326-4

13. Soon IS, Molodecky NA, Rabi DM, Ghali WA, Barkema HW, Kaplan GG. The relationship between urban environment and the inflammatory bowel diseases: a systematic review and meta-analysis. BMC Gastroenterol. 2012;12:51, http://dx.doi. org/10.1186/1471-230X-12-51

14. Rogler G, Zeitz J, Biedermann L. The search for causative environmental factors in inflammatory bowel disease. Dig Dis. 2016;34(1):48-55, http://dx.doi.org/10.1159/000447283

15. Ljubičić N, Bišćanin A, Nikić I, Budimir I, Nikolić M, Pavić T. Endoscopic balloon dilatation of postsurgical intestinal strictures in Crohn's disease: case report and review of the literature. Acta Clin Croat. 2013; 52(3):374-9.

16. Bilski J, Mazur-Bialy A, Brzozowski B, Magierowski M, Zahhradnik-Bilska J, Wo'jcik D, et al. Can exercise affect the course of inflammatory bowel disease? Experimental and clinical evidence. Pharmacol Rep. 2016;68(4):827-36, http://dx. doi.org/10.1016/j.pharep.2016.04.009

17. DeFilippis EM, Tabani S, Warren RU, Christos PJ, Bosworth BP, Scherl EJ. Exercise and self-reported limitations in patients with inflammatory bowel disease. Dig Dis Sci. 2016;61(1): 215-20, http://dx.doi.org/10.1007/s10620-015-3832-4

18. Cheifetz AS, Gianotti R, Luber R, Gibson PR. Complementary and alternative medicines used by patients with inflammatory bowel diseases. Gastroenterology. 2017;152(2):415-29, http://dx.doi.org/10.1053/j.gastro.2016.10.004 
19. Jones PD, Kappelman MD, Martin CF, Chen W, Sandler RS, Long MD. Exercise decreases risk of future active disease in inflammatory bowel disease patients in remission. Inflamm Bowel Dis. 2015;21(5):1063-71, http://dx.doi.org/10.1097/ MIB.0000000000000333

20. Klare P, Nigg J, Nold J, Haller B, Krug AB, Mair S, et al. The impact of a ten-week physical exercise program on health-related quality of life in patients with inflammatory bowel disease: a prospective randomized controlled trial. Digestion. 2015;91(3):239-47, http://dx.doi.org/10.1159/000371795

21. Detels R, Gulliford M, Karim QA, Tan CC. Oxford Textbook of Global Public Health. $6^{\text {th }}$ edn. Oxford: Oxford University Press; 2015. Chapter 5, Statistical methods; p. 613-33.

22. Chan D, Robbins H, Rogers S, Clark S, Poullis A. Inflammatory bowel disease and exercise: results of a Crohn's and Colitis UK survey. Frontline Gastroenterol. 2014;5(1):44-8, http:// dx.doi.org/10.1136/flgastro-2013-100339

23. Tew GA, Jones K, Mikocka-Walus A. Physical activity habits, limitations, and predictors in people with inflammatory bowel disease: a large cross-sectional online survey. Inflamm Bowel Dis. 2016;22(12):2933-42, http://dx.doi.org/10.1097/MIB.00 00000000000962

24. D'Inca R, Garribba AT, Vettorato MG, Martin A, Martines D, Di Leo $V$, et al. Use of alternative and complementary therapies by inflammatory bowel disease patients in an Italian tertiary referral centre. Dig Liver Dis. 2007;39(6):524-9, http://dx.doi. org/10.1016/j.dld.2007.03.001

25. Mack DE, Wilson PM, Gilmore JC, Gunnell KE. Leisuretime physical activity in Canadians living with Crohn disease and ulcerative colitis: population-based estimates. Gastroenterol Nurs. 2011;34(4):288-94, http://dx.doi.org/10.1097/ SGA.0b013e3182248732

26. Wang Q, Xu KQ, Qin XR, Wen-Lu, Yan-Liu, Wang XY. Association between physical activity and inflammatory bowel disease risk: a meta-analysis. Dig Liver Dis. 2016;48(12): 1425-31, http://dx.doi.org/10.1016/j.dld.2016.08.129

27. Burisch J. Crohn's disease and ulcerative colitis. Occurrence, course and prognosis during the first year of disease in a European population-based inception cohort. Dan Med J. 2014; 61(1): B4778.

28. Carbonnel F, Hugot JP. Which environmental factors cause IBD relapses? Dig Dis Sci. 2015;60(5):1129-31, http://dx.doi. org/10.1007/s10620-015-3570-7

29. Engels M, Cross RK, Long MD. Exercise in patients with inflammatory bowel diseases: current perspectives. Clin Exp Gastroenterol. 2017;11:1-11, http://dx.doi.org/10.2147/CEG. S120816

30. Lykouras D, Karkoulias K, Triantos C. Physical exercise in patients with inflammatory bowel disease. J Crohns Colitis. 2017; 11(8):1024, http://dx.doi.org/10.1093/ecco-jcc/jjx006

31. Perez CA. Prescription of physical exercise in Crohn's disease. J Crohns Colitis. 2009;3(4):225-31, http://dx.doi.org/10.1016/ j.crohns.2009.08.006
32. Bilski J, Mazur-Bialy AI, Wierdak M, Brzozowski T. The impact of physical activity and nutrition on inflammatory bowel disease: the potential role of cross talk between adipose tissue and skeletal muscle. J Physiol Pharmacol. 2013;64(2):143-55.

33. Shepard RJ. The case for increased physical activity in chronic inflammatory bowel disease: a brief review. Int J Sports Med. 2016;37(7):505-15, http://dx.doi.org/10.1055/s-0042-103157

34. Abegunde AT, Muhammad BH, Owais Bhatti O, Ali T. Environmental risk factor for inflammatory bowel diseases: evidence based literature review. World J Gastroenterol. 2016; 22:6296-317, http://dx.doi.org/10.3748/wjg.v22.i27.6296

35. Packer N, Hoffman-Goetz L, Ward G. Does physical activity affect quality of life, disease symptoms and immune measures in patients with inflammatory bowel disease? A systematic review. J Sports Med Phys Fitness. 2010;50(1):1-18.

36. Narula N, Fedorak RN. Exercise and inflammatory bowel disease. Can J Gastroenterol. 2008;22(5):497-504.

37. Nathan I, Norton C, Czuber-Dochan W, Forbes A. Exercise in individuals with inflammatory bowel disease. Gastroenterol Nurs. 2013;36(6):437-42, http://dx.doi.org/10.1097/SGA.00 00000000000005

38. Loudon CP, Coroll V, Butcher J, Pawsthorne P, Bernstein CN. The effects of physical exercise on patients with Crohn's disease. Am J Gastroenterol. 1999;94(3):697-703, http://dx.doi.org/ 10.1111/j.1572-0241.1999.00939.x

39. $\mathrm{Ng}$ V, Millard W, Lebrun C, Howard J. Low-intensity exercise improves quality of life in patients with Crohn's disease. Clin J Sports Med. 2007;17(5):384-8, http://dx.doi.org/10.1097/ JSM.0b013e31802b4fda

40. Niu J, Miao J, Tang Y, Nan Q, Liu Y, Yang G, et al. Identification of environmental factors associated with inflammatory bowel disease in a Southwestern Highland Region of China: a nested case-control study. PLoS One. 2016;11(4):e0153524, http://dx.doi.org/10.1371/journal.pone.0153524

41. Ng SC, Tang W, Leong RW, Chen M, Ko Y, Studd C, et al. Environmental risk factors in inflammatory bowel disease: a population-based case-control study in Asia-Pacific. Gut. 2015; 64(7):1063-71, http://dx.doi.org/10.1136/gutjnl-2014-307410

42. Martin D. Physical activity benefits and risks of exercise on the gastrointestinal system. South Med J. 2011;104 (12):831-7, http://dx.doi.org/10.1097/SMJ.0b013e318236c263

43. Lovén Wickman U, Yngman-Uhlin P, Hjortswang H, Riegel B, Stjernman H, Hollman Frisman G. Self-care among patients with inflammatory bowel disease: an interview study. Gastroenterol Nurs. 2016;39(2):121-8, http://dx.doi.org/10.1097/ SGA.0000000000000120

44. van Langenberg DR, Gibson PR. Factors associated with physical and cognitive fatigue in patients with Crohn's disease: a cross-sectional and longitudinal study. Inflamm Bowel Dis. 2014;20(1):115-25, http://dx.doi.org/10.1097/01.MIB.00004 37614.91258 .70 
Sažetak

\title{
UČINAK DNEVNE TJELESNE AKTIVNOSTI NA AKTIVNOST UPALNIH BOLESTI CRIJEVA KOD BOLESNIKA KOJI NE UZIMAJU TERAPIJU
}

\author{
D. Holik, A. Vcerev, A. Milostić-Srb, Ž. Salinger, Z. Ivanišević, I. Včev i M. Miškulin
}

Smatra se kako različiti okolišni čimbenici igraju vrlo važnu ulogu u etiologiji upalnih bolesti crijeva (UBC) te kako imaju značajan učinak na tijek ovih bolesti. Cilj ovog istraživanja bio je ispitati učinak dnevne tjelesne aktivnosti na aktivnost UBC kod bolesnika koji ne uzimaju terapiju. Ovo presječno populacijsko istraživanje provedeno je u istočnoj Hrvatskoj od siječnja do lipnja 2016. godine. Istraživanje je obuhvatilo 312 bolesnika srednje dobi $49,9 \pm 15,0$ godina; $53,2 \%$ muškaraca i 46,8\% žena; 63,4\% oboljelih od ulcerativnog kolitisa (UC) i 36,6\% oboljelih od Crohnove bolesti (CB). Sociodemografska obilježja bolesnika, podaci o njihovoj dnevnoj tjelesnoj aktivnosti i vrsti terapije koju uzimaju prikupljeni su pomoću posebno dizajniranog i validiranog upitnika, dok je aktivnost UC i CB ocijenjena primjenom indeksa Mayo i indeksa HarveyBradshaw. Istraživanje je pokazalo kako $24,0 \%$ bolesnika ne uzima terapiju. Dnevna tjelesna aktivnost bila je povezana s neaktivnom UBC kod bolesnika kada su zajednički promatrane obje bolesti (Fisherov egzaktni test; $p<0,001$ ) te je bila povezana s neaktivnošću CB (Fisherov egzaktni test; $\mathrm{p}=0,001$ ) i UC (Fisherov egzaktni test, $\mathrm{p}=0,006$ ) kad je svaka bolest promatrana zasebno. Dnevna tjelesna aktivnost povezana je s neaktivnošću UBC kod bolesnika koji ne uzimaju terapiju. Potrebno je sve bolesnike s UBC podučiti o važnosti tjelesne aktivnosti za kontrolu njihove bolesti.

Ključne riječi: Upalne bolesti crijeva; Kolitis, ulcerozni; Crohnova bolest; Vježbanje; Hrvatska 